\title{
A Study on the PBL Teaching Model Applied to Academic English Teaching under the Background of Subject-based College English Teaching
}

\author{
Li Jiang ${ }^{1, \text { a }}$ \\ ${ }^{1}$ Nanchang Institute of Science and Technology, 330108 \\ ajianglijx@126.com
}

Keywords: problem-based learning; academic English; subject-based teaching

\begin{abstract}
PBL is a teaching method regarding problems as its orientation. It is a new learning model that students study in dependently under the lead of teacher. PBL mainly emphasize students' collaboration and group leaning. The application of PBL model in college English teaching is increasing, as the result of the advocating of modern vocational education in China at present. The using of PBL model can improve students' logical thinking ability, learning ability and language communication ability, which can meet the social need for language talents.

Along with the advance of modern vocational education, it is necessary for the establishment of a wholesome modern vocational education system. It has been quite important to introduce new teaching method in college English teaching in order to ensure that our graduates can adapt to the current social development, and meet the social demand for comprehensive and applied English talents. There are still many problems in academic English teaching in China, displaying that English teaching in basic stage overlap with college English teaching; students have little enthusiasm in English learning; Unitary teaching mode in English classroom teaching, can not stimulate students interest in English learning; The current teaching mode can't satisfy the cultivation to the modern professional talents and the requirement of modern vocational education development of society.
\end{abstract}

\section{PBL Teaching model}

PBL model was developed from the Problem-based Teaching Method which was first put forward by American educator John Dewey in the 1950s. It is such a teaching model that students form study groups and work together to complete problems or tasks assigned by the teacher through forming study groups under the guide of the teacher, and teaching tasks are completed on the basis of autonomic learning and with the help of interaction among students. The PBL teaching model has been applied in different fields and disciplines at present. PBL teaching model is firstly used in College English teaching in China in the beginning of 21st century. The employment of this teaching model could help improve students' interest in English learning and self innovation ability. The construction of the connection between English and society, English and enterprise in the process of English learning is beneficial for the improvement of students' English application ability and the provide of English talents for country modernization.

\section{The importance of application of PBL teaching model to academic English teaching under the background of subject-based teaching}

Under the background of subject-based teaching, the traditional teaching model with teachers as center and students in a passive position could not meet the demand of current social economic development and the need for talents. The significance of PBL teaching model can be highlighted through analysis of the advantage of them.

College English is not only a subject but also but also a course complying with the demand social development. If the college English teaching and the teaching results fail to conform to society and era development, it will gradually die. The application of FBL model can help stimulate 
students' learning consciousness and enthusiasm, and help students' exploratory learning through the conduct of English learning programs. Moreover, it can help students improve their language ability, creativity, practical ability, and thinking ability during the course of learning. Application of PBL teaching model not only can meet the need of the current enterprise for talents strategy, also can provide a sustainable path of college English.

Because college students choose various majors, they only learn in order to mater their expertise in the process of English leaning. If there is not stimulation of English circumstance during the course of learning, the purpose of students learning English will appear deviation, which will influence students' enthusiasm. In the traditional classroom teaching, teachers take force-feeding teaching methods and students lack the consciousness of participation and learning motivation. The application of PBL teaching model can help students actively participate in the teaching design and classroom teaching process, and students can have clear understanding of their learning goals and learning methods. It can also help improve students' sense of identity with English classroom teaching and sense of engagement through long-term training. If the PBL teaching mode is applied academic English teaching, these teaching methods such as long debate, discussion, speech and so on will often be adopted in teaching process. It can help students develop the consciousness and ability of teamwork by the team cooperation. It can also build up their confidence in English learning through mutual help and encouragement.

The application of PBL teaching model can mainly help develop students' consciousness and creativity of English leaning. Teachers and students can create classroom learning atmosphere together. Students can build ingenious knowledge system independently under the instruction and help of teachers. Teachers are not the center of class any more but the director role. They help students develop the spirit of exploration and the thirst for knowledge by giving class time to students in order to make students play their initiative and creativity freely. It conforms to the trend of academic English teaching under the background of subject-based teaching.

\section{The Application of PBL Teaching Model in Academic English Teaching}

By applying PBL teaching model in college English teaching, students are divided into several groups, and they are assigned with different learning tasks according to their learning abilities. Students can display their solutions and outcomes with the help of language, words, videos, PPT etc, and then they can find the existing problems through the reviews of students and teachers and improve them. The application of the PBL teaching model is mainly divided into the stage before project, project implementation, and the stage after project, these three important stages. Details are showed in table 1.

Table 1 PBL teaching model

\begin{tabular}{|c|l|}
\hline \multirow{2}{*}{ the stage before project } & $\begin{array}{l}\text { 1. Introducing the learning characteristics related to PBL, } \\
\text { namely evaluation criteria 2. Introducing the project 3. } \\
\text { Students implement the project plan. } 4 \text {. The teacher gives } \\
\text { their suggestions on the students' plan. 5. Students revise } \\
\text { their plan. }\end{array}$ \\
\hline project implementation stage & $\begin{array}{l}\text { 1. Students carry out the project according to the plan } \\
\text { 2.The project is completed. }\end{array}$ \\
\hline the stage after project & $\begin{array}{l}\text { 1. Students display their outcomes of the project } \\
\text { 2.Students and teachers assess and summarize the project. }\end{array}$ \\
\hline
\end{tabular}

Before the PBL teaching model is applied, teachers need introduce this model to students. Because students have been influenced deeply by the traditional teaching model, it will take a period of time for them to accept the teaching model. Teachers can let students accept the new teaching model by introducing the advantages, using method, and purposes etc of the PBL teaching model. After students have some knowledge of PBL teaching model, they can adjust their learning activities to keep consistent with the teaching pace. In order to improve the students' enthusiasm of 
English learning, teachers should rank the difficulty of the questions, and assign tasks according to students' learning conditions. However, the question can't be too easy and lacks challenge and leaning significance. Teacher can instruct students when they are collecting materials and discussing. Students share and explain their outcomes in class, meanwhile, students can improve their oral English practice and learning confidence. Teachers can make some complement for the existing problems, and guide students improve their project. In order to ensure the learning effect and the effectiveness of the implementation of the PBL teaching model, students can make written reports such as learning summary etc in each semester, and make a statement in English class before the end of the semester. This part can also be listed as a semester grade evaluation. In addition, to encourage students to express his opinions is conducive to improve the effect of the application of PBL teaching mode in English teaching.

\section{Summary}

PBL teaching model can emphasize students' independent learning ability and concern the process students discuss and solve the problems, which can improve students' learning ability. Through the application of PBL teaching mode in class, students complete to search materials and process information and information exchange etc through group work in the process of finishing the assigned learning tasks by teachers. in complete tasks assigned by the teacher, which is very significant to improve their thinking ability, learning ability, and the ability to do classroom reports etc.

\section{References}

[1] Song Ziying. A Necessary Study on the Application of PBL Teaching Mode in College English Teaching[J]. Theoretic Observation, 2015, 04:174-175.

[2]Li Xiaohong, Liyue, Zhanglei. The Problems and Countermeasures of College English Hierarchical Teaching under the Background of PBL Teaching Mode[J]. Journal of Hebei United University (Social Science Edition), 2015, 03:130-133.

[3]Xiao Wenjuan, Ma Yongliang, Xuejing. The Application of PBL Teaching Mode in College English Teaching under the Environment of Mooc[J]. Journal of Changchun college of education,2015, 01:85-86.

[4] Cheng Hongmei. The Application of PBL Teaching Mode in College English Teaching under the Network Environment [J]. Journal of Hebei University of Engineering (Social Science Edition), 2015, 0 2: 127-129.

[5] Cheng Zhan. The Application of PBL Teaching Mode in College English Teaching [J]. Journal of Jiamusi institute of education, 2013, 07: 392+395.

[6] He Yidan. A Study on College English Network Aided PBL Teaching Mode [J]. The Asia-pacific education, 2016, 05: 177-178. 